\title{
PENGARUH LEADER MEMBER EXCHANGE, DAN KEAHLIAN TEKNOLOGI INFORMASI TERHADAP KINERJA GURU SMP DI KABUPATEN PURWAKARTA
}

\author{
Oleh : \\ Patoni \\ Program Studi Manajemen - STIE Dr. Khez Muttaqien Purwakarta \\ Email: patonipkn@gmail.com
}

\begin{tabular}{l}
\hline Article Info \\
\hline Article History : \\
Received 23 July - 2020 \\
Accepted 20 August - 2020 \\
Available Online \\
07 Sept - 2020
\end{tabular}

Keyword :

Member Exchange Leader,

Information Technology,

Teacher Performance

\begin{abstract}
The Patoni. 2020. This research is subject to the influence of Exchange Member leaders, and information technology expertise to the performance of SMP teachers in Purwakarta regency. The purpose of this research is to know the influence of member exchange leaders, and the expertise of information technology to the performance of SMP teachers in Purwakarta district with the research method used is descriptive analytical. Research Data obtained from questionnaires directly disseminated to 95 junior high school teachers in Purwakarta district which spread over 51 SMPN through Google form. Data processing is conducted using SPSS version 24.0 program which includes validity test, reliability test, correlation test, multiple linear regression test, and classical assumption test. The results showed that partial member exchange leaders significantly affect the performance of SMP teachers in Purwakarta District by $54.40 \%$, and the expertise of information technology significantly affect the performance of SMP teachers in Purwakarta District by $49.30 \%$. Simultaneously shows the significant influence of member exchange leaders and information technology expertise to the performance of junior high school teachers in Purwakarta district of $64.21 \%$ and the remaining $35.79 \%$ are influenced by other factors that are not researched by researchers.
\end{abstract}

\section{PENDAHULUAN}

Pendidikan merupakan aktivitas seluruh manusia yang diyakini dapat menerangi dan memfasilitasi seluruh kebutuhan manusia dalam berbagai sektor kehidupan. Suryadi, (2002: 1), "Pendidikan dipandang sebagai katalisator utama dalam pengembangan sumber daya manusia, dengan anggapan bahwa semakin terdidik seseorang, semakin tinggi pula kesadarannya terhadap kesehatan, partisipasi politik dan keluarga berencana". UNESCO mendeskripsikan pendidikan dengan empat pilar, yaitu 1) Learning to know 2) Learning to do, 3) Learning to be dan 4) Learning to live together.
Dinamika pembangunan pendidikan di Kabupaten Purwakarta secara tersurat tertuang dalam Peraturan Bupati Purwakarta Nomor 69 tahun 2015 tentang pendidikan karakter. Salah satu point penting dalam Peraturan Bupati tersebut adalah konsepsi 7 poe atikan pendidikan Purwakarta Istimewa yaitu senin ajeg nusantara, selasa mapag buana, rabu maneh di sunda, kamis nyanding wawangi, jumat nyucikeun diri, sabtu dan minggu betah diimah.

Guru sebagai sumber daya utama dalam bidang pendidikan di Kabupaten Purwakarta berdasarkan data SIMPEG Kabupaten Purwakarta per 31 Desember 2017, diketahui 
jumlah guru sebesar 4073 orang, jumlah aparatur sipil negara se kabupaten berjumlah 8101 orang artinya bahwa 50, 28\% SDM adalah guru. Jumlah yang besar belum tentu berkontribusi besar terhadap pencapaian tujuan. Kualitas kerja atau kinerja merupakan hal esensial dalam proses pencapaian tujuan organisasi. Asf \& Mustofa (2013:155-156), menjelaskan bahwa kinerja guru adalah hasil kerja yang dapat dicapai oleh seorang guru di lembaga pendidikan sesuai dengan tugas dan tanggung jawab dalam mencapai tujuan pendidikan. Kinerja guru adalah keseluruhan produk guru sesuai dengan rencana yang sudah disusun sebelumnya. Keberhasilan seorang guru harus memenuhi kriteria yang telah ditetapkan, apabila guru telah memenuhi kriteria tersebut berarti seorang guru dapat dikatakan berhasil dan memiliki kualitas yang baik.

Kinerja guru di Kabupaten Purwakarta berdasarkan pra survey melalui kuesioner google form pada umumnya baik namun harus ditingkatkan karena tuntutan perkembangan jaman terus berubah. Berdasarkan data pra survey diperoleh informasi bahwa kinerja guru masih harus ditingkatkan.
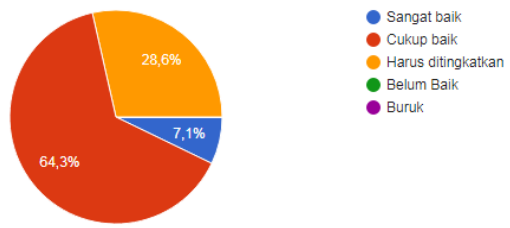

Hasil pra survey tersebut memberikan informasi bahwa $64,3 \%$ responden mengatakan kinerja guru cukup baik, 28,6\% mengatakan kinerja guru harus ditingkatkan, dan hanya $7,1 \%$ mengatakan kinerja guru sangat baik. Kinerja guru masih harus ditingkatkan berakibat pada beberapa persoalan yang sering muncul terkait dengan kinerja guru antara lain pengisian PUPNS, input data dapodik, pengisian SKP dan PKG, pengisan eRapot, SIM PKB, terlambatnya kenaikan pangkat/golongan, pembuatan bahan ajar dalam bentuk PPT, menyusun analisis hasil ujian, menginput rata-rata harian siswa sebagai bahan dasar eRapot dan persoalan lainnya yang berhubungan dengan keterlaksanaan tugas pokok dan fungsi guru. Variatif masalah di setiap satuan pendidikan akan berhubungan dengan kepemimpinan sekolahnya, persepsi diri terhadap tugas keguruan indvidu, kemampuan teknologi informasi dari guru yang bersangkutan, sarana sekolah, letak geografis sekolah, jumlah guru dan lain sebagainya.
ASf \& Mustofa (2013:160) menyebutkan bahwa faktor yang memengaruhi kinerja guru dapat berasal dari dalam individu itu sendiri seperti motivasi, keahlian, dan juga pendidikan. Ada juga faktor dari luar individu seperti iklim kerja, tingkat gaji, dan lain sebagainya. Djoko Purwanto, 2006 dalam Martiningsih (2015) mengemukakan bahwa keberhasilan dan kegagalan sebuah perusahaan di pengaruhi oleh seorang pemimpin, kepemimpinan yang efektif memberi dampak kemajuan pada perusahaan.

Berdasarkan pra survey melalui google form diperoleh informasi bahwa kinerja guru di Kabupaten Purwakarta, dipengaruhi oleh berbagai faktor yang salah satunya adalah praktik kepemimpinan kepala sekolah. Berdasarkan data dapat diperoleh informasi bahwa 39,3\% mengatakan kinerja guru dipengaruhi oleh praktik kepemimpinan kepala sekolah, 28,65 \% dipengaruhi oleh kesejahtraan, dan $17,9 \%$ dipengaruhi oleh kondosivitas sekolah. Informasi ini memberi makna bahwa pemimpin memiliki peran strategis dalam konteks kinerja pegawainya, oleh sebab itu seorang pemimpin harus memiliki kompetensi dan pengetahuan manajerial dan strategi yang baik, berperilaku yang baik, mampu mempengaruhi dan mengarahkan orang lain, mampu mengambil keputusan dan mampu melakukan pendekatan personal serta mampu menerapkan kepemimpinanya sesuai dengan karakteristik lingkungan organisasi masing-masing dan situasi global yang sedang sedang berkembang.

Satu model kepemimpinan yang dipandang berkontribusi terhadap kinerja pegawai/karyawan adalah leader member exchange. Leader member exchange adalah teori pertukaran pemimpin-anggota menggambarkan bagaimana para pemimpin mengembangkan hubungan pertukaran yang berbeda sepanjang waktu dengan bawahan. Hasil penelitian Wang (2016); Arsintadiani dan Harsono (2012) menyatakan bahwa leader member exchange berpengaruh terhadap kinerja karyawan. Pemimpin menyampaikan harapan peran untuk pengikut mereka dan memberikan imbalan berwujud dan tidak berwujud untuk pengikut yang memenuhi harapan tersebut. Demikian juga, pengikut memegang harapan peran pemimpin mereka, sehubungan dengan bagaimana mereka diperlakukan dan penghargaan mereka untuk menerima untuk memenuhi harapan pemimpin. 
Praktik kepemimpinan leader member exhange menggambarkan pengikut tidak pasif "penerima peran"; mereka mungkin baik menolak, memeluk, atau menegosiasikan peran yang ditentukan oleh pemimpin mereka. Ada proses timbal balik antara pemimpin dan pengikut, dimana masing-masing pihak membawa ke hubungan berbagai jenis sumber daya untuk pertukaran.

Faktor lainnya yang diduga berpengaruh terhadai kinerja guru adalah keahlian TIK guru masing-masing. Teknologi informasi dan komunikasi yang terus mengalami kemajuan akan mempengaruhi pola komunikasi masyarakat nantinya (Sudarwan, 2010). Menurut Tandeur, et.al., (2006) : "Information and Communication Technology (ICT) plays an important role in society when we take into account the social, cultural and economic role of computers and the Internet." Oleh karena itu, mengintegerasikan TI dalam aspek pendidikan merupakan hal yang sangat penting saat ini.

(2015) menunjukkan bahwa tingkat pengetahuan TIK guru matematika SMA/MA Di Kabupaten Tanjung Jabung Barat berada pada kategori rendah. Tingkat keahlian TIK guru berada pada kategori sedang dan tingkat implementasi TIK guru berada pada tingkat "rendah". Realitas tersebut memberi informasi bahwa keahlian IT guru dalam melaksanakan tugas keguruannya masih harus ditingkatkan.

Kabupaten Purwakarta yang sangat konsen dengan pendidikan dan berfokus pada peningkatan keahlian teknologi informasi guru sebagai salah satu faktor yang mempengaruhi kinerja gurunya ternyata belum menggembirakan. Berdasarkan pra survey didapat informasi bahwa keahlian teknologi informasi guru di SMP di Kabupaten Purwakarta dari responden yang memberikan tanggapan, keahlian teknologi informasi guru perlu ditingkatkan karena belum baik.

Berdasarkan data pra survey diperoleh informasi bahwa $60,7 \%$ responden menyebutkan keahlian teknologi informasi guru baru yang mampu/ahli, 32,1\% mengatakan bahwa baru lima puluh persen guru yang ahli dalam teknologi informasi. Tuntutan pada pembelajaran abad-21, guru harus mampu menggunakan teknologi informasi sebagai media dan sumber belajar yang salah satunya dengan menggunakan akses internet. Internet merupakan sumber informasi yang tak terbatas (Slamet, 2009). Selain mampu menggunakan TI sebagai sumber belajar, guru juga dituntut untuk mampu menciptakan pembelajaran kreatif dan inovatif yang terintegrasi. Profil pemanfaatan teknologi informasi dan komunikasi, penguasaan teknologi informasi dan komunikasi, merupakan salah satu kompetensi yang sangat penting bagi guru. Peraturan Menteri pendidikan Nasional nomor 16 Tahun 2007 mengenai Standar Kualifikasi Akademik dan Kompetensi Guru, terdapat empat kompetensi yang harus dikuasai oleh guru, dua diantaranya adalah kompetensi pedagogik dan kompetensi profesional. Kedua kompetensi tersebut sangat erat kaitannya dengan pemanfaatkan TI dalam pembelajaran.

Keahlian IT guru yang belum baik tentu akan berpengaruh pada pencapaian target pekerjaan guru baik dalam persiapan, pelaksanaan maupun dalam evaluasi. Berdasarkan data prasurvey melalui google form diperoleh informasi bahwa masih terdapat kendala dalam proses peningkatan kinerja guru yang salah satunya adalah keahlian IT.
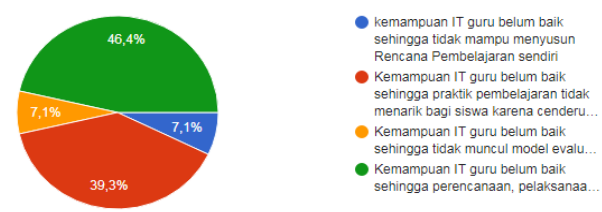

Bedasarkan gambar tersebut diperoleh informasi bahwa $46,4 \%$ responden mengatakan bahwa kemampuan IT guru belum baik sehingga perencanaan pembelajaran tidak optimal, 39,3\% mengatakan bahwa kemampuan IT guru belum baik sehingga berpengaruh pada praktik pembelajaran. Hasil studi pendahuluan melalui observasi dan wawancara, peneliti menemukan bahwa di lingkungan Dinas Pendidikan Kabupaten Purwakarta masih terdapat kelemahan dalam pemanfaatan teknologi informasi. Peneliti melihat bahwa sebagian guru terutama guru mata pelajaran yang sudah senior (lama mengabdi dan berusia 50 tahun lebih) belum terampil dalam memanfaatkan teknologi informasi untuk menunjang pelaksanaan tugastugasnya padahal kemampuan teknologi informasi dalam praktik pembelajaran dan pelaporan hasil belajar peserta didik bisa lebih menarik dan efektif.

\section{KERANGKA PEMIKIRAN PENGEMBANGAN HIPOTESIS Leader Member Exchange}

Leader member exchange merupakan suatu model praktik kepemimpinan yang sangat memperhatikan kualitas hubungan 
timbal balik antara pemimpin dan karyawan dalam sebuah organisasi. Menurut Asgari, dkk (2008) teori pertukaran pemimpin anggota didasarkan pada asumsi bahwa para pemimpin membangun hubungan pertukaran sosial dengan karyawan mereka dan sifat hubungan pertukaran ini adalah bagaimana pemimpin memperlakukan setiap karyawan. Suhermin (2012) mengemukakan bahwa leader member exchange berfokus pada kualitas pertukaran hubungan antara karyawan dan manajer, didasarkan pada tingkat dukungan emosional dan pertukaran sumber daya yang dihargai. Leader member exchange tidak hanya sebatas hubungan kerja saja, tetapi teori ini juga menunjang baik pemimpin maupun karyawan untuk saling memberi feedback satu sama lainnya.

Liden dan Graen (1980) dalam Muhaimin 2011, menjelaskan bahwa leader member exchange merupakan suatu hubungan yang saling mempengaruhi antara atasan dengan bawahan, dimana atasan meberikan tipe hubungan yang berbeda terhadap bawahan-bawahannya secara individual. Leader member exchange merupakan hubungan timbal balik yang melibatkan komunikasi antara pemimpin dan karyawan melalui keakraban antar satu dan lainnya, berkontribusi untuk sesama saling setia dan mempunyai rasa hormat antar individu. Hubungan baik antara pemimpin dan karyawan diharapkan dapat meningkatkan kinerja perusahaan.

Figur menjadi titik sentral bagi terlaksananya roda organisasi. Figur yang menggerakan semua sub-sistem organisasi tersebut, oleh karena itu figure harus memiliki hubungan yang harmonis dengan seluruh karyawannya. Leader member exchange dapat menjadi solusi terbentuknya hubungan harmonis antara pemimpin dengan anggotanya. Miner (1988) mengemukakan bahwa interaksi atasan bawahan yang berkualitas tinggi akan memberikan dampak seperti meningkatnya kepuasan kerja, produktivitas, dan kinerja pegawai. Interaksi atau hubungan yang dijalin oleh tiap karyawan dan pemimpin tentunya berbeda-beda antara satu dengan yang lainnya. Truckenbrodt (2000, p.234) mengatakan bahwa dalam sebuah organisasi dilihat dari hubungan dan interaksi antara pemimpin dan karyawan dapat dikelompokkan menjadi dua kelompok, yaitu:

a. In-group : Dalam hubungan ini, karyawan dan pemimpin memiliki hubungan yang baik, hubungan antar keduanya didasarkan oleh perasaan senasib, rasa percaya, dan afeksi terhadap satu sama lain.

b. Out - group : Dalam hubungan ini, posisi pemimpin terhadap karyawan lebih ke arah profesional. Hal ini disebabkan karena begitu minim waktu yang disediakan untuk mendekatkan diri, sehingga karyawan lebih memiliki sedikit waktu untuk pemimpin, dan hubungan antar keduanya hanya dalam koridor interaksi otoritas yang normal.

Konsepsi leader member exchange maka dapat dimulai dengan memahami dimensidimesinya. Liden dan Maslyn (1998, p.50) membagi leader member exchange menjadi empat dimensi, antara lain :

a. Affect (Afeksi )

Affect mengacu pada keakraban antara satu individu dengan individu lainnya. Liden dan Maslyn (1998, p. 46) menambahkan bahwa aspek afeksi dapat menjadi unsur paling dominan maupun tidaknya dapat bergantung kepada jenis hubungan yang ada di tempat kerja.

b. Contribution (Kontribusi)

Liden dan Maslyn (1998, p.50) menyatakan bahwa dimensi kontribusi adalah persepsi tentang kegiatan yang berorientasi pada tugas di tingkat tertentu antara pemimpin dan karyawan untuk mencapai tujuan bersama.

3. Loyalty (Loyalitas)

Loyalty adalah kesetiaan dan dukungan yang diberikan pada individu lain, baik itu karyawan maupun pemimpin. Liden dan Maslyn (1998, p.50) menyatakan bahwa loyalitas adalah bagaimana pemimpin maupun karyawan saling mendukung aksi dan karakter satu sama lainnya dalam segala situasi.

4. Professional Respect (Respek/ Hormat)

Professional respect mengacu pada rasa hormat atau kagum pada pekerjaan yang dilakukan orang lain. yang disebabkan karena reputasi yang dimiliki oleh pemimpinnya. Liden dan Maslyn (1998, p.50) bahwa reputasi dapat terbentuk melalui data sejarah mengenai seorang pribadi seperti pengalaman pribadi, komentar yang didapat melalui perseorangan maupun dari luar organisasi dan penghargaan yang diberikan terhadapnya.

\section{Keahlian Teknologi Informasi Guru}

Teknologi informasi pada era globalisasi menjadi bagian dari kebutuhan kehidupan setiap orang. UNESCO bekerjasama dengan 
CISCO, Intel, dan Microsoft, serta para ahli pendidikan melakukan konsultasi intensif untuk mengidentifikasi kompetensi TIK guru yang dimilikinya agar dapat menguasai materi dan kelas secara efektif dan efisien. Dari hasil kerjasama menghasilkan tiga buku kerangka kerja UNESCO mengenai kompetensi TIK bagi guru profesional yang diterbitkan pada tahun 2008, yaitu:

a. Kerangka Kebijakan yang menjelaskan mengenai alasan, struktur dan pendekatan kegiatan ICT-CFT (ICT Competency Framework for Teachers project),

b. Kerangka kompetensi pengembangan modul yang dapat menjelaskan bagaimana tiga tahap pembangunan pendidikan dapat dipetakan terhadap enam aspek pekerjaan seorang guru untuk menciptakan kerangka 18 modul kompetensi guru, dan

c. Pedoman pelaksanaan yang disediakan secara spesifik dan rinci untuk setiap modul dalam pembangunan pendidikan.

Pemanfaatan teknologi informasi pada dunia pendidikan didasarkan tiga pendekatan yaitu :

a. Technology Literacy, yaitu dengan meningkatkan sejauhmana teknologi digunakan oleh siswa, masyarakat, dan tenaga kerja dengan memasukkan keterampilan teknologi ke dalam kurikulum sekolah yang mampu meningkatkan keterampilan belajar siswa.

b. Knowledge Deepening yaitu meningkatkan kemampuan siswa, masyarakat, dan tenaga kerja dalam menggunakan pengetahuan untuk menambah nilai masyarakat dan produktivitas ekonomi dengan menerapkan permasalahan kompleks di dunia nyata.

c. Knowledge Creation yaitu meningkatkan kemampuan siswa, masyarakat, dan tenaga kerja untuk berinovasi menghasilkan pengetahuan baru dan memperoleh manfaat dari pengetahuan baru. Teknologi informasi dijadikan sarana kreativitas manusia dalam mencukupi seluruh kebutuhan hidupnya terlebih dengan teknologi informasi proses pemenuhan kebutuhan manusia dalam berbagai bidang akurasi dan kecepatanya terukur.

Keahlian teknologi informasi yang dapat membantu pelaksanaan tugas-tugas guru antara lain :

a. Teknologi informasi sebagai keterampilan (skill) dan kompetensi

b. Teknologi informasi sebagai bahan ajar

c. Teknologi informasi sebagai infrastruktur pembelajaran d. Teknologi informasi sebagai manajemen pembelajaran,

e. Teknologi informasi sebagai sistem pendukung pembelajaran

\section{Kinerja Guru}

Kinerja merupakan suatu konsep yang bersifat universal yang merupakan efektifitas operasional suatu organisasi, bagian organisasi, dan karyawannya berdasarkan standar dan kriteria yang telah ditetapkan sebelumnya. Kinerja bagi suatu organisasi merupakan unsur penting dalam pencapaian tujuan organisasi. Dessler (1997: 513) menyatakan bahwa kinerja hampir sama dengan prestasi kerja ialah perbandingan antara hasil kerja actual dengan standar kerja yang ditetapkan. Marwansyah (2016:229) menyatakan bahwa kinerja atau unjuk kerja adalah pencapaian atau prestasi seseorang berkenaan dengan tugas-tugas yang dibebankan kepadanya.

Kinerja guru pada prinsipnya merupakan spesifikasi pekerjaan yang harus dilaksanakan semua yang berprofesi guru. Tabrani Rusyan dkk, (2000:17), mengemukakan bahwa kinerja guru adalah melaksanakan proses pembelajaran baik dilakukan di dalam kelas maupun di luar kelas di samping mengerjakan kegiatan-kegiatan lainnya, seperti mengerjakan administrasi sekolah dan administrasi pembelajaran, melaksanakan bimbingan dan layanan pada para siswa, serta melaksanakan penilaian. Soedijarto (1993) bahwa kemampuan yang harus dikuasai oleh seorang guru, yaitu:

a. Merencanakan program belajar mengajar;

b. Melaksanakan dan memimpin proses belajar mengajar;

c. Menilai kemajuan proses belajar mengajar;

d. Membina hubungan dengan peserta didik.

UU No. 14 Tahun 2005 Bab IV Pasal 20

(a) tentang Guru dan Dosen menyatakan bahwa standar prestasi kerja guru dalam melaksanakan tugas keprofesionalannya, guru berkewajiban merencanakan pembelajaran, melaksanakan proses pembelajaran yang bermutu serta menilai dan mengevaluasi hasil pembelajaran. Permendiknas No. 41 Tahun 2007 menunjukan beban kerja guru mencakup kegiatan pokok: (1) merencanakan pembelajaran; (2) melaksanakan pembelajaran; (3) menilai hasil pembelajaran; (4) membimbing dan melatih peserta didik; dan (5) melaksanakan tugas tambahan. Kinerja guru dapat dilihat saat dia melaksanakan interaksi belajar mengajar di kelas termasuk 
persiapannya baik dalam bentuk program semester maupun persiapan mengajar.

Kinerja seseorang pada umumnya bukan variabel yang berdiri sendiri tetapi mendapat pengaruh dari berbagai faktor. Simanjuntak (2011:11) mengemukakan tiga faktor yang mempengaruhi kinerja seseorang yaitu kompensasi individu yang bersangkutan, dukungan organisasi, dan dukungan manejemen. Menurut Surya (2004: 10) bahwa faktor yang mempengaruhi kinerja guru adalah yang mendasar dan terkait erat dengan kinerja professional guru adalah kepuasan kerja yang berkaitan erat dengan kesejahteraan guru.

Arif Ramdhani (2011:27) yang menjelaskan delapan dimensi pengukuran kinerja berdasarkan teori Dessler:
a. Pemahaman
b. Kualitas/kuantitas kerja,
c. Perencanaan,
d. Inisiatif/komitmen
e. Penyelesaian.
f. Kerja tim dan kerjasama,.
g. Kemampuan berhubungan dengan orang lain,

h. Komunikasi (lisan dan tulisan)

Untuk mengukur kinerja karyawan secara individual dikemukakan Robbins, (2002:260) ada enam kriteria, yaitu 1) Kualitas 2) Kuantitas, 3) Ketepatan waktu, , 4) Efektivitas, 5) Kemandirian, 6) komitmen kerja. , yang merupakan tingkat dimana karyawan mempunyai komitmen kerja dengan instansi dan tanggung jawab terhadap organisasi.

\section{Pengembangan Hipotesis Penelitian}

Berdasarkan landasan teoritis dan kerangka berpikir yang telah dikemukakan terdahulu, maka dapat diajukan hipotesis sebagai berikut :

a. Leader member exchange dan keahlian teknologi informasi berpengaruh terhadap kinerja guru di Kabupaten Purwakarta.

b. Leader member exchange berpengaruh terhadap kinerja guru di Kabupaten Purwakarta

c. Keahlian teknologi informasi berpengaruh terhadap kinerja guru di Kabupaten Purwakarta.

\section{METODE PENELITIAN}

Metode dalam penelitian ini adalah metode deskriptif dengan pendekatan kuantitatif yang menitikberatkan pada pengujian hipotesis dalam menghasilkan suatu kesimpulan. Penelitian deskriptif, diharapkan dapat diperoleh deskripsi bagaimana pengaruh leader member exchange, dan keahlian teknologi informasi terhadap kinerja guru SMP di Kabupaten Purwakarta. Sugiono (2008) mengemukakan bahwa penelitian kuantitatif adalah penelitian dengan memperoleh data yang berbentuk angka atau data kualitatif yang diangkakan. Penelitian kuantitatif dilaksanakan untuk menguji ada atau tidaknya pengaruh variabel independen yaitu leader member exchange, dan keahlian teknologi informasi terhadap variabel dependent yaitu kinerja guru SMP di Kabupaten Purwakarta. Teknik pengumpulan data melalui observasi, Studi kepustakaan, kuesioner. Populasinya berjumlah 1430 yang tersebar pada 51 satuan pendidikan jenjang SMP di Kabupaten Purwakarta dan sampelnya 95 orang guru.

\section{HASIL PENELITIAN DAN PEMBAHASAN}

\section{Pengaruh Leader Member Exchange Terhadap Kinerja Guru SMP di Kabupaten Puwakarta}

Variabel leader member exchange berpengaruh signifikan terhadap variabel kinerja guru SMP di kabupaten Purwakarta sebesar 54,4\%. Realitas ini menunjukkan pembuktian terhadap apa yang dikemukakan oleh Liden dan Graen (1980) dalam Muhaimin 2011, dimana leader member exchange merupakan suatu hubungan yang saling mempengaruhi antara atasan dengan bawahan, dimana atasan meberikan tipe hubungan yang berbeda terhadap bawahan-bawahannya secara individual. Miner (1988) mengemukakan bahwa interaksi atasan bawahan yang berkualitas tinggi akan memberikan dampak seperti meningkatnya kepuasan kerja, produktivitas, dan kinerja pegawai. Kualitas hubungan kepala sekolah sebagai leader dengan guru sebagai bawahannya akan berpengaruh terhadap kinerja masing-masing individu yaitu kepala sekolah dan gurunya.

Penguatan lainnya dikemukakan oleh Rousseau (1989) yang mengatakan bahwa Leader member exchange berhubungan dengan employee engagement, dimana leader member exchange merupakan aspek penting dalam kehidupan organisasi yang mempengaruhi hasil perilaku serta sebagai proses keterlibatan. Asgari, dkk (2008) bahwa para pemimpin (leader) membangun hubungan pertukaran sosial dengan karyawan mereka dan sifat hubungan pertukaran ini adalah bagaimana pemimpin memperlakukan setiap karyawan. 
Hasil penelitian ini juga menunjukkan bahwa tingkat kepercayaan guru terhadap kemampuan kerja kepala sekolahnya sebagai leader berada pada level yang sangat bagus. Penilaian ini tentu saja bukan mudah tetapi setidaknya sebagai bentuk responsif karyawan atau guru terhadap kepala sekolah yang dalam praktik kepemimpinannya mengutakan kualitas hubungan. Apa yang dikemukakan Saks (2006) dan Suhermin (2012) dimana leader member exchange berfokus pada kualitas pertukaran hubungan antara karyawan dan manajer, didasarkan pada tingkat dukungan emosional dan pertukaran sumber daya yang dihargai akan menunjang baik pemimpin maupun karyawan untuk saling memberi feedback satu sama lainnya.

Temuan lain dari penelitian ini adalah apa yang tertera pada tabel 4.6 dimana $63,20 \%$ responden memberi tanggapan sangat setuju terhadap indikator kepala sekolah memiliki hubungan yang harmonis dengan seluruh warga sekolah dalam melaksanakan tugasnya. Fakta ini memberikan membuktikan bahwa leader member exchange merupakan hubungan timbal balik yang melibatkan komunikasi antara pemimpin dan karyawan melalui keakraban antar satu dan lainnya, berkontribusi untuk sesama, saling setia dan mempunyai rasa hormat antar individu. Keterlibatan komunikasi yang akrab antara kepala sekolah sebagai leader dengan seluruh warga sekolah didasarkan pada apa yang dikemukakan oleh Liden dan Maslyn (1998, p.50) yaitu aspek afeksi (Affect), kontribusi (Contribution), loyalitas, dan professional respect (respek / hormat)

\section{Pengaruh Keahlian Teknologi Komunikasi Terhadap Kinerja Guru SMP di Kabupaten Puwakarta}

Berdasarkan olah data SPPS 24.0 diperoleh nilai korelasi atau hubungan $(\mathrm{R})$ yaitu sebesar 0,541 dan dijelaskan berdasarkan presentasenya pengaruh variable $\mathrm{X} 3$ terhadap variabel $\mathrm{Y}$ atau yang disebut dengan koefisien determinasi yang merupakan hasil dari pengudratan nilai $R$. dari output diatas diperoleh nilai R2 atau KD ( koefisien determinasi) sebesar 0,493 yang mengandung arti bahwa pengaruh variable $\mathrm{X} 3$ atau keahlian teknologi informasi terhadap variable $\mathrm{Y}$ kinerja guru SMP di kabupaten Purwakarta adalah sebesar 49,3\%, sedangkan 50,7 \% dipengaruhi konstruk di lain diluar konstruk penelitian.
Hasil penelitian ini memberi penguatan bahwa memang teknologi informasi pada era globalisasi menjadi bagian kebutuhan kehidupan setiap orang. Teknologi informasi dibutuhkan oleh semua orang tanpa membedakan status sosial, ekonomi, politik, jabatan jenis kelamin dan lainnya. UNESCO (United Nations Educational, Scientific and Cultural Organization) telah membuat suatu kerangka kompetensi Tecnology Information (TI) dalam proses belajar mengajar. Unesco memandang bahwa dengan adanya teknologi informasi, proses pembelajaran akan semakin mudah dan cepat berkembang.

Tanggapan responden pada keseluruhan indikator tentang indikator saya mampu mengoperasikan komputer program word, power point, excel dan akses internet dan tentang indikator saya mampu memperkaya bahan ajar dengan memanfaatkan program power point dan akses internet, dimana lebih dari $90 \%$ menyatakan sangat setuju dan setuju memberikan informasi bahwa teknologi informasi di lingkungan guru SMP kabupaten Purwakarta telah menjadi sarana dan daya dukung pembelajaran, baik dalam tataran perencanaan, pelaksanaan maupun evaluasi pembelajaran.

Temuan ini sesuai dengan tiga pendekatan dalam teknologi informasi jika dihubungan dengan pendidikan yaitu :

1. Technology Literacy, yaitu dengan meningkatkan sejauhmana teknologi digunakan oleh siswa, masyarakat, dan tenaga kerja dengan memasukkan keterampilan teknologi ke dalam kurikulum sekolah.

2. Knowledge Deepening yaitu meningkatkan kemampuan siswa, masyarakat, dan tenaga kerja dalam menggunakan pengetahuan untuk menambah nilai masyarakat dan produktivitas ekonomi dengan menerapkan permasalahan kompleks di dunia nyata.

3. Knowledge Creation yaitu meningkatkan kemampuan siswa, masyarakat, dan tenaga kerja untuk berinovasi menghasilkan pengetahuan baru dan memperoleh manfaat dari pengetahuan baru.

\section{Implikasi Hasil Penelitian Terhadap Manajemen SDM}

Berdasarkan tabel coefficients, didapat nilai constant 3.579 sedangkan nilai X1 (leader member exchange) 0, 543X2 () 0.516 dan X2 (Keahlian Teknologi Informasi) 0,463. sehingga didapat persamaan regresinya sebagai 
berikut $: \mathrm{Y}=3.579+0.543 \mathrm{X} 1++0.463 \mathrm{X} 2$. artinya :

1. Konstanta sebesar 3.579 menyatakan bahwa jika tidak ada nilai Leader Member Exchange, dan Keahlian Teknologi Informasi maka nilai Kinerja Guru adalah sebesar 3.579.

2. Koefisien regresi berganda X1 sebesar 0.543 menyatakan bahwa setiap penambahan nilai 1 Leader Member Exchange, maka nilai Kinerja Guru bertambah sebesar 0.543

3. Koefisien regresi Berganda X2 sebesar 0.516 menyatakan bahwa setiap penambahan nilai 1 , maka nilai Kinerja Guru bertambah sebesar 0.516

4. Koefisien regresi Berganda X3 sebesar 0.463 menyatakan bahwa setiap penambahan nilai 1 Keahlian Teknologi Informasi, maka nilai Kinerja Guru bertambah sebesar 0.463

Secara umum dapat diartikan semakin bertambah nilai leader member exchange, dan keahlian teknologi informasi maka semakin tinggi pengaruhnya terhap nilai kinerja guru. Makna kinerja seperti dikemukakan Dessler (1997: 513), Wirawan (2017:790), Marwansyah (2016:229) dan Anwar Prabu Mangkunegara (2014:67) pada intinya adalah hasil pencapaian kerja, kualitas dan kuantitas kerja seseorang atau hasil kerja secara kualitas dan kuantitas yang dicapai seseorang karyawan dalam melaksanakan tugasnya sesuai dengan tanggung jawab dalam praktiknya tentu ditentukan oleh berbagai faktor.

Oleh karena itu implikasi manajerial sumber daya manusia adalah bagaimana setiap organisasi memahami karakteristik SDM nya sehingga menbuka ruang peningkatan kinerja. Dalam konteks ini Dinas Pendidikan sebagai top manajerial terdekat dari kepala sekolah harus memiliki kemampuan professional dalam proses recruitment kepala sekolahnya karena kepala sekolah menjadi varibel yang signifikan untuk mempengaruhi kinerja guru. Selain proses perencanaan SDM atau rekruitmen tentu pembinaan dan pengembangan kompetensi dari para kepala sekolah harus terus ditingkatkan untuk mencapai kualitas dan kuantitas kinerja yang maksimal.

Demikian halnya dengan kepala sekolah sebagai top manajerial di sekolah harus memiliki komptensi, visi dan misi terhadap organisasi yang dipimpinnya, karena kepala sekolah menjadi variabel yang signifikan untuk mempengaruhi kinerja guru. Kepala sekolah harus memiliki hubungan kerja yang harmonis, demokratis dan menjadi tauladan bagi seluruh warga sekolah sehingga guru termotivasi untuk menunjukan kinerja terbaiknya. Mulyasa (2007: 227) mengemukakan bahwa sedikitnya terdapat sepuluh faktor yang dapat meningkatkan kinerja guru, baik faktor internal maupun eksternal, yaitu "Kesepuluh faktor tersebut adalah: (1) dorongan untuk bekerja, (2) tanggung jawab terhadap tugas, (3) minat terhadap tugas, (4) penghargaan terhadap tugas, (5) peluang untuk berkembang, (6) perhatian dari kepala sekolah, (7) hubungan interpersonal dengan sesama guru, (8) MGMP dan KKG,(9) kelompok diskusi terbimbing serta,(10) layanan perpustakaan".

Guru sebagai ujung tombak pelaksanaan fungsi pendidikan disekolah tentu saja tidak bergantung seluruhnya kepada kepala sekolah. Kemampuan guru menginterpretasi peran dan fungsinya serta kemampuan teknologi informasi sebagai konsekuensi era globalisasi menjadi variabel yang signifikan terhadap peningkatan kinerja guru. Oleh sebab itu guru harus menginvestasikan waktu untuk terus meningkatkan persepsi peran dan kompetensinya dalam segala bidang sehingga membuka peluang peningkatan kinerjanya.

Pada akhirnya setiap sub system sumber daya manusia dalam suatu organisasi menjadi penentu tercapainya tujuan organisasi, setiap sub system memiliki peran dan tanggung jawab tersendiri, dan kewajiban leaderlah atau kepala sekolah mengkombinasi setiap potensi individu yang ada dalam organisasi tersebut. Pengakuan dan pengahargaan terhadap potensi anggota organisasi menjadi sangat penting karena peningkatan kinerja terbaiknya.

\section{KESIMPULAN}

a. Secara simultan leader member exchange, dan keahlian teknologi informasi berpengaruh positif sebasar 64,21\% terhadap kinerja guru SMP di Kabupaten Purwakarta. Sehingga sisanya sebesar $35,79 \%$ dipengaruhi oleh faktor lain yang tidak diteliti dalam penelitian ini.

b. Secara parsial Leader member exchange berpengaruh positif sebesar 54,40\% terhadap kinerja guru SMP di Kabupaten Purwakarta.

c. Secara parsial keahlian teknologi informasi berpengaruh positif terhadap kinerja guru SMP di Kabupaten Purwakarta sebesar 49, $30 \%$. 
6. REFERENSI

A.A. Prabu Mangkunegara (2014). Manajemen Sumberdaya Manusia. Bandung. PT. Remaja Rosdakarya.

Ana Rasyidah1)* Jefri Marzal2) M.Damris Edu-Sains Volume 4 No. 2, Juli 201537 Investigasi

Pengetahuan, Keterampilan Dan Implementasi Teknologi Informasi dan Komunikasi (TIK) Guru Matematika SMA/MA Di Kabupaten Tanjung Jabung Barat

Arif Ramdhani (2011) Penilaian Kinerja. Bandung. PT Sarana Panca Karya Nusa

Arsintadiani, D., \& Harsono, M. (2002). Pengaruh tingkat LMX terhadap penilaian kerja dan kepuasan kerja dengan kesamaan jender dan locus of control sebagai variabel moderator, 7 , 113-122

Asf Jasmani \& Syaiful Mustofa. (2013). Terobosan Baru dalam Kinerja Peningkatan Kerja Pengawas Sekolah dan Guru. Jogjakarta: Ar-Ruzz Media

Asgari Ali, Abu Daud Silong, Aminah Ahmad dan Bahaman Abu Samah. 2008. "The relationship between leader-member exchange, organizational inflexibility, perceived organizational support, interactional justice and organizational citizenship behaviour". African Journal of Business Management, Vol.2, No 8

Churchill. (2001). Sales

Force Management $\left(7^{\text {th }}\right.$ ed.). New Jersey: Prentice Hall

Saleh, D. S., \& Imbari, S. (2019). KAJIAN PRODUCTION EMPHASIS, PENGEMBANGAN KARIR PROTEAN, DAN KOMPENSASI SOSIAL PADA KINERJA KARYAWAN DENGAN KEPUASAN KERJA SEBAGAI VARIABEL MEDIASI. Eqien: Jurnal Ekonomi dan Bisnis, 6(2), 17-27.

Danim dan Darwis (2003) Metode Penelitian Kebidanan. Jakarta PT Pustaka Pelajar

Dian Kartika, Suharnomo Dipenogoro (2016) Journal of Management Volume 5, nomor 2 tahun 2016

Darmadi Hamid (2013) Metode Penelitian Pendidikan dan Sosial. Bandung Alfabeta Deliarnov

Garry Dessler (2017 ) Manajemen Sumber Daya Manusia. Jakarta Salemba Empat

Gibson. James, (1987) Organisasi dan Manajemen Perilaku, Struktur, Proses Jakarta. PT Gramedia Pustaka
Graen, G. B., \& Uhl-Bien, M. (1995). The relationship-based approach to leadership: Development of LMX theory of leadership over 25 years: Applying a multi-level, multi-domain perspective. Leadership Quarterly, 6(2), 219-247

Hasibuan, Malayu S.P., (1997), Manajemen Sumber Daya Manusia, PT Toko Gunung Agung, Jakarta

Hani Handoko, (1994) Manajemen Personalia dan Sumber Daya Manusia. Yogyakarta. Haji Masagung

Hanif Taqiuddin ${ }^{1}$, Irsan Tricahyadinata ${ }^{2}$, Alexander Sampeliling 2018, FORUM EKONOMI ISSN Print: 1411-1713 ISSN Online: 2528-150X

Hui Wang (2005) Leader-Member Exchange As A Mediator Of The Relationship Between Transformational Leadership And Followers' Performance And Organizational Citizenship Behavior Peking University

Kadir,Abdul dan Triwahyuni, Terra. 2003. Teknologi

Pengendalian Yogjakarta: Andi

Kameswara Bayu S.A. (2015) Progam Studi Akuntansi Fakultas Ekonomi Dan Bisnis Universitas Muhammadiyah Surakarta 2015 Naskah Publikasi

Liden, R. C., \& Maslyn, J. M. (1998). Multidimensionality of leader-member exchange: An empirical asessment through scale development, Journal of Management, 24 (1), 43-72

Mangkupawira (2001) Sumbr Daya Manusia dan Produktivitas Kerja CV Mandar Maju

Marwansyah (2016) Manajemen Sumber Daya Manusia. Bandung : Alfabeta

Moeheriono. 2012. "Pengukuran Kinerja Berbasis Kompetensi”. Jakarta: Raja Grafindo Persada

Muhaimin Kunartinah (2011) Peran Karakteristik Kepribadian Leader Member Exchange dan Lingkungan Kerja terhadap kinerja karyawan PT Matahari Silverindo Jaya (MSJ) Semarang. Jurnal Program Studi Manajemen Universitas Stikubank

Mike A.K. Lovihan (2014) JURNAL PSIKOLOGI TABULARASA VOLUME 9, NO.2, OKTOBER 2014: $99-108$

Miner, J.B. 1988. Organizational Behavior: Performance and Productivity. New York: Random House, Inc. 
Mulyasa, E., (2007) Standar Kompetensi Guru Dan Sertifikasi, Bandung: Remaja Rosdakarya, 2006

Mukhammad Hilmi Muzakki, Heru Susilo Saiful Rahman Yuniarto Fakultas Ilmu Administrasi Universitas Brawijaya Malang Jurnal Administrasi Bisnis (JAB)|Vol. 39 No.2 Oktober 2016| administrasibisnis.studentjournal.ub.ac.i $d$

Murtiningsih (2015) Pengaruh Gaya Kepemimpinan Transformasional Pada Kinerja Perawat Rumah Sakit Islam Siti Aisyah Madiun. DAYA SAING Jurnal Ekonomi Manajemen Sumber Daya Vol. 17, No. 2, Desember 2015

Mutia Sari, Hasan Basri dan Mirna Lindriani Jurnal Magister Akuntansi Pascasarjana Universitas Syiah Kuala

Nazir (2014) Metode Penelitian. Bogor PT Ghalia Indonesia

Patrick Hutama (2017), Pengaruh Leader Member Exchange terhadap Kinerja Karyawan di Hotel X Surabaya Program Manajemen Perhotelan, Fakultas Ekonomi, Universitas Kristen Petra. Jurnal volume 5 No.2

Rani Angraeni, Ria Nelly Sari \& Susilatri Jurnal Akuntansi, Vol. 6, No. 2, April $2018: 143-157$

Ridwan dan Sunarto (2013), Pengantar Statistika Jakarta Bumi Aksara

Rousseau, D. M. (1989). "Psychological and Implied Contracts in Organizations". Employee Responsibilities and Rights Journal, Vol.8

Saks, Alan M. 2006. "Antecedents and consequences of employee engagement". Journal of Managerial Psychology, Vol. 21, No.7

Simanjuntak, Payaman J. (2011) Manajemen \& Evaluasi Kinerja. Jakarta:Fakultas Ekonomi Universitas Indonesia
Sugiyono. (2012). Metode Penelitian, Kuantitatif, Kualitatif, dan R\&D. Bandung: Alfabeta.

Sugiyono. 2013. Statistika Untuk Penelitian. Bandung: Alfabeta

Sugiyono (2014) Metode Penelitian Kuantitatif-Kualitatif dan R\&D. Bandung Alfabeta

Sumantri, E. (2003) Pendidikan Politik. Pusat Penerbitan Universitas Terbuka Jakarta

Surya, Mohamad (2004) Psikologi Pembelajaran dan Pengajaran. Bandung Pustaka Bani Quraisy Sanjaya

Suryadi, A. (2002) Pendidikan Investasi SDM dan Pembangunan, Jakarta Balai Pustaka

Tabrani Rusyan dkk. (2000) Upaya Meningkatkan Budaya Kinerja Guru, Cianjur: CV. Dinamika Karya Cipta

Tasya Via Tanaro ${ }^{1}$, Teguh Widodo, $e$ Proceeding of Management : Vol.5, No.3 Desember 2018 | Page 3228

Thoha, M. 2007. Perilaku Organisasi, Konsep Dasar dan Aplikasinya. Jakarta: PT. Raja Grafindo Persada

Truckenbrodt, Y. B. (2000). The relationship between leader-member exchange and commitment and organizational citizenship behavior, Acquistion Review Quarterly, 233-244

Umar, Husein. (2008) Desain Penelitian Akuntansi Keprilakuan. Jakarta: PT. Raja Grafindo Persada

Wirawan ( 2017) Kepemimpinan Teori, Psikologi, Perilaku Organisasi, Aplikasi dan Penelitian, Jakarta PT Raja Grafindo Persada

Yukl, Gary. 2005. Kepemimpinan Dalam Organisasi, Edisi Kelima, Alih Bahasa: Budi Suprianto. PT Indeks Kelompok Gramedia. Jakarta 